\title{
Preparation and Crystal Structure of $\left[\left(\mathrm{Me}_{3} \mathrm{Si}\right)_{2} \mathrm{~N}_{2} \mathrm{TeCl}_{2}\right.$
}

\author{
Jarkko Pietikäinen, ${ }^{a}$ Risto S. Laitinen ${ }^{a, *}$ and Jussi Valkonen ${ }^{b}$

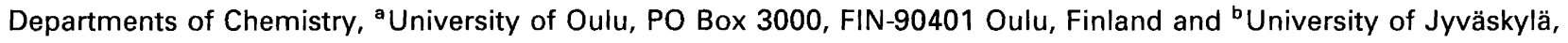 \\ PO Box 35, FIN-40350 Jyväskylä, Finland
}

\begin{abstract}
Pietikäinen, J., Laitinen, R. S. and Valkonen, J., 1999. Preparation and Crystal Structure of $\left[\left(\mathrm{Me}_{3} \mathrm{Si}\right)_{2} \mathrm{~N}_{2} \mathrm{TeCl}_{2}\right.$. - Acta Chem. Scand. 53: 963-967. (C) Acta Chemica Scandinavica 1999.

$\left[\left(\mathrm{Me}_{3} \mathrm{Si}\right)_{2} \mathrm{~N}\right]_{2} \mathrm{TeCl}_{2}$ can be prepared in good yields by treating $\left[\left(\mathrm{Me}_{3} \mathrm{Si}\right)_{2} \mathrm{~N}\right]_{2} \mathrm{Te}$ with an equimolar amount of $\mathrm{SO}_{2} \mathrm{Cl}_{2}$. The almost colourless crystals are monoclinic with space group $P 2 / c$ having the unit cell parameters $a=8.517(2)$, $b=11.667(2), c=24.376(5) \AA, \beta=91.05(3)^{\circ}, V=2421.8(9) \AA^{3}, Z=4$. The molecule is monomeric, containing four-coordinated tellurium of trigonal bipyramidal geometry with the two chlorine atoms occupying axial positions and the two $\left(\mathrm{Me}_{3} \mathrm{Si}\right)_{2} \mathrm{~N}$ substituents two equatorial positions. The third equatorial position holds the tellurium lone-pair. The short $\mathrm{Te}-\mathrm{N}$ and $\mathrm{Si}-\mathrm{N}$ bonds and the long $\mathrm{Te}-\mathrm{Cl}$ bonds can be understood in terms of a delocalized $\pi$-electron distribution in the equatorial plane and its interaction with the axial chlorine atoms. A comparison of structural and spectroscopic trends in analogous molecular species supports this bonding scheme. Close intermolecular $\mathrm{Te} \cdots \mathrm{Cl}$ contacts expand the coordination sphere of tellurium to six.
\end{abstract}

Whereas studies of sulfur-nitrogen compounds have seen considerable progress during recent decades, ${ }^{1-4}$ selenium-nitrogen and tellurium-nitrogen chemistry has evolved much more slowly. Recent years, however, have seen a growing interest in the chemistry of these heavier chalcogen-nitrogen species. ${ }^{5-7}$ While analogous sulfurnitrogen and selenium-nitrogen compounds often have similar monomeric molecular structures, the telluriumnitrogen species are often oligomeric or polymeric. This is exemplified by tellurium diimides, which are dimeric, ${ }^{8-10}$ in contrast to monomeric sulfur ${ }^{11,12}$ and selenium diimides. ${ }^{13}$

Bis $\left[(\right.$ trimethylsilyl ) amino $]$ chalcogenides $\left[\left(\mathrm{Me}_{3} \mathrm{Si}\right)_{2} \mathrm{~N}\right]_{2} \mathrm{E}$ $(\mathrm{E}=\mathrm{S}, \mathrm{Se})$ have turned out to be useful reagents. They react with chalcogen halogenides to produce cyclic chalcogen nitrides. For example, tetrasulfur tetranitride $\mathrm{S}_{4} \mathrm{~N}_{4}$ can be prepared in good yields by the reaction of $\left[\left(\mathrm{Me}_{3} \mathrm{Si}\right)_{2} \mathrm{~N}\right]_{2} \mathrm{~S}$ with equimolar amounts of $\mathrm{SO}_{2} \mathrm{Cl}_{2}$ and $\mathrm{SCl}_{2} .{ }^{14,15}$ Tetraselenium tetranitride can also conveniently be prepared by an analogous reaction involving $\left[\left(\mathrm{Me}_{3} \mathrm{Si}\right)_{2} \mathrm{~N}\right]_{2} \mathrm{Se}$ and $\mathrm{SeCl}_{4} \cdot{ }^{16}$ The existence of the corresponding $\mathrm{Te}_{4} \mathrm{~N}_{4}$ has been suggested, ${ }^{17,18}$ but there is no structural information. The preparation of $\mathrm{Te}_{4} \mathrm{~N}_{3}$ has also been reported. ${ }^{19}$

This work is a part of a systematic study to produce heterochalcogen nitrides. We have recently shown that $1,5-\mathrm{Se}_{2} \mathrm{~S}_{2} \mathrm{~N}_{4}$ is produced in good yields, when $\left[\left(\mathrm{Me}_{3} \mathrm{Si}\right)_{2} \mathrm{~N}\right]_{2} \mathrm{~S}$ is treated with $\mathrm{SeCl}_{4}$ or $\left[\left(\mathrm{Me}_{3} \mathrm{Si}\right)_{2} \mathrm{~N}\right]_{2} \mathrm{Se}$ is treated with $\mathrm{SO}_{2} \mathrm{Cl}_{2}$ and $\mathrm{SCl}_{2} \cdot{ }^{20,21}$ The corresponding

\footnotetext{
* To whom correspondence should be addressed.
}

reaction of $\left[\left(\mathrm{Me}_{3} \mathrm{Si}\right)_{2} \mathrm{~N}\right]_{2} \mathrm{~S}$ with $\mathrm{TeCl}_{4}$ has been reported to form $\mathrm{Cl}_{2}$ TeNSNTe. ${ }^{22}$ This paper describes an attempt to produce 1,5- $\mathrm{Te}_{2} \mathrm{~S}_{2} \mathrm{~N}_{4}$ by the reaction of $\left[\left(\mathrm{Me}_{3} \mathrm{Si}\right)_{2} \mathrm{~N}\right]_{2} \mathrm{Te}$ with $\mathrm{SO}_{2} \mathrm{Cl}_{2}$ and $\mathrm{SCl}_{2}$ that surprisingly resulted in the formation of a chlorinated aminotellurane $\left[\left(\mathrm{Me}_{3} \mathrm{Si}\right)_{2} \mathrm{~N}\right]_{2} \mathrm{TeCl}_{2}$ with a similar monomeric structure as found previously in $\mathrm{MeN}(\mathrm{PhBNMe})_{2} \mathrm{TeCl}_{2}{ }^{23}$ and $\left(\mathrm{Ph}_{3} \mathrm{PN}\right)_{2} \mathrm{TeCl}_{2} .{ }^{24}$ This paper describes a modified synthesis of $\left[\left(\mathrm{Me}_{3} \mathrm{Si}\right)_{2} \mathrm{~N}\right]_{2} \mathrm{TeCl}_{2}$ from $\left[\left(\mathrm{Me}_{3} \mathrm{Si}\right)_{2} \mathrm{~N}\right]_{2} \mathrm{Te}$ and $\mathrm{SO}_{2} \mathrm{Cl}_{2}$ together with the structural characterization of the product.

\section{Experimental}

General. All reactions were carried out under a dry argon atmosphere that was passed through $\mathrm{P}_{4} \mathrm{O}_{10}$ before use. $\left(\mathrm{Me}_{3} \mathrm{Si}\right)_{2} \mathrm{NH}$ (Aldrich), $n$-BuLi $(2.5 \mathrm{M}$ in hexanes, Aldrich) and $\mathrm{TeCl}_{4}$ (Aldrich) were used without further purification. $\mathrm{SO}_{2} \mathrm{Cl}_{2}$ (Aldrich) was purified by fractional distillation over $\mathrm{P}_{4} \mathrm{O}_{10}$. $\left[\left(\mathrm{Me}_{3} \mathrm{Si}\right)_{2} \mathrm{~N}\right]_{2} \mathrm{Te}$ was prepared from $\left(\mathrm{Me}_{3} \mathrm{Si}\right)_{2} \mathrm{NH}, n$-BuLi and $\mathrm{TeCl}_{4}$ as reported by Björgvinsson et al. $^{25}$ The solvents were dried by fresh distillation under a nitrogen atmosphere: Diethyl ether (Lab Scan) and $n$-hexane (Lab Scan) over Na/benzophenone, and toluene (Lab Scan) over $\mathrm{LiAlH}_{4}$.

Preparation of $\left[\left(\mathrm{Me}_{3} \mathrm{Si}\right)_{2} \mathrm{~N}_{2} \mathrm{TeCl}_{2} . \quad\left[\left(\mathrm{Me}_{3} \mathrm{Si}\right)_{2} \mathrm{~N}_{2} \mathrm{Te}\right.\right.$ $\left(1.466 \mathrm{~g}, 3.27 \mathrm{mmol}\right.$ ) was dissolved in $30 \mathrm{~cm}^{3}$ of $n$ hexane, and a solution of $0.441 \mathrm{~g}(3.27 \mathrm{mmol})$ of $\mathrm{SO}_{2} \mathrm{Cl}_{2}$ in $20 \mathrm{~cm}^{3}$ of $n$-hexane was added at $-78^{\circ} \mathrm{C}$. The solution was stirred for $2 \mathrm{~h}$ and allowed to warm up to room 
temperature. The solvent was removed under vacuum and a white precipitate was obtained. Recrystallization from small amount of $n$-hexane yielded $1.526 \mathrm{~g} \mathrm{(90 \% )} \mathrm{of}$ almost colorless crystals of $\left[\left(\mathrm{Me}_{3} \mathrm{Si}\right)_{2} \mathrm{~N}\right]_{2} \mathrm{TeCl}_{2}$. Anal. Calcd. for $\mathrm{C}_{12} \mathrm{H}_{36} \mathrm{Si}_{4} \mathrm{~N}_{2} \mathrm{TeCl}_{2}$ : C, 27.76; H, 6.99; N, 5.39. Found: C, 26.33; H, 7.06; N, 5.43. Spectroscopic data: NMR (in $n$-hexane): ${ }^{1} \mathrm{H} \delta=0.07 \mathrm{ppm} ;{ }^{13} \mathrm{C} \delta=1.01 \mathrm{ppm}$, ${ }^{1} J_{\mathrm{HC}}=118 \mathrm{~Hz} ;{ }^{14} \mathrm{~N} \delta=-312 \mathrm{ppm} ;{ }^{125} \mathrm{Te} \delta=1510 \mathrm{ppm}$. IR ( KBr) v/ $\mathrm{cm}^{-1}: 3402 \mathrm{~m}, 3149 \mathrm{vs}, 3053 \mathrm{vs}, 2958 \mathrm{~s}, 2899 \mathrm{~m}$, $2807 \mathrm{~m}, 1450 \mathrm{sh}, 1402 \mathrm{vs}, 1252 \mathrm{~s}, 1053 \mathrm{w}, 884 \mathrm{~s}, 842 \mathrm{vs}, 788 \mathrm{w}$, $754 \mathrm{~m}, 711 \mathrm{w}, 623 \mathrm{~m}$. Raman (solid) v/ $\mathrm{cm}^{-1}$ : 2995w, $2966 \mathrm{~m}, 2901 \mathrm{~s}, 1410 \mathrm{v}, 1260 \mathrm{vw}, 1248 \mathrm{vw}, 804 \mathrm{vw}, 756 \mathrm{vw}$, $731 \mathrm{w}, 682 \mathrm{~m}, 640 \mathrm{~s}, 398 \mathrm{~m}, 357 \mathrm{w}, 286 \mathrm{~m}, 253 \mathrm{vs}, 245 \mathrm{sh}$, $191 \mathrm{~m}, \quad 140 \mathrm{~s}, \quad 113 \mathrm{~s} . \quad \mathrm{MS}: \quad m / z=486 \quad\{2 \%$, $\left.\left[\left(\mathrm{Me}_{3} \mathrm{Si}\right)_{2} \mathrm{~N}\right]_{2} \mathrm{TeCl}^{+}\right\}, 451\left\{20 \%,\left[\left(\mathrm{Me}_{3} \mathrm{Si}\right)_{2} \mathrm{~N}\right]_{2} \mathrm{Te}^{+}\right\}, 447$ $\left[13 \%,\left(\mathrm{Me}_{3} \mathrm{Si}\right)_{3} \mathrm{~N}_{2} \mathrm{TeCl}_{2}{ }^{+}\right], 378\left[5 \%,\left(\mathrm{Me}_{3} \mathrm{Si}\right)_{3} \mathrm{~N}_{2} \mathrm{Te}^{+}\right]$, $361 \quad\left[6 \%, \quad\left(\mathrm{Me}_{3} \mathrm{Si}\right)_{2} \mathrm{NTeCl}_{2}{ }^{+}\right], \quad 326 \quad[6 \%$, $\left.\left(\mathrm{Me}_{3} \mathrm{Si}\right)_{2} \mathrm{NTeCl}^{+}\right], \quad 288 \quad\left(11 \%, \quad \mathrm{Me}_{3} \mathrm{SiNTeCl}_{2}{ }^{+}\right), \quad 276$ $(45 \%, ?), 217\left(4 \%, \mathrm{Me}_{3} \mathrm{SiNTe}^{+}\right), 146\left[100 \%,\left(\mathrm{Me}_{3} \mathrm{Si}\right)_{2}{ }^{+}\right]$, $130\left(34 \%, \mathrm{Te}^{+}\right), 93(76 \%, ?), 75\left(35 \%, \mathrm{Me}_{3} \mathrm{Si}^{+}\right)$.

Note! $\left[\left(\mathrm{Me}_{3} \mathrm{Si}\right)_{2} \mathrm{~N}\right]_{2} \mathrm{TeCl}_{2}$ is air- and moisture-sensitive and should always be handled under an inert atmosphere to avoid decomposition.

Spectroscopy. The ${ }^{1} \mathrm{H},{ }^{13} \mathrm{C},{ }^{14} \mathrm{~N}$ and ${ }^{125} \mathrm{Te}$ NMR spectra were recorded at $300 \mathrm{~K}$ on a Bruker DPX 400 spectrometer operating at $400.00,100.61,28.915$ and $126.240 \mathrm{MHz}$ for ${ }^{1} \mathrm{H},{ }^{13} \mathrm{C},{ }^{14} \mathrm{~N}$ and ${ }^{125} \mathrm{Te}$, respectively. The spectral widths for ${ }^{13} \mathrm{C},{ }^{14} \mathrm{~N}$ and ${ }^{125} \mathrm{Te}$ spectra were $35.21,13.02$ and $126.58 \mathrm{kHz}$, yielding the respective resolutions of $1.07,12.72$ and $3.86 \mathrm{~Hz} /$ data point. The pulse width for ${ }^{13} \mathrm{C}$ was $4.0 \mu \mathrm{s}$, for ${ }^{14} \mathrm{~N} 12.00 \mu \mathrm{s}$ and for ${ }^{125} \mathrm{Te} 6.67 \mu$ s, corresponding to nuclear tip angles of 40.0 , 44.1 and $30.0^{\circ}$, respectively. The ${ }^{1} \mathrm{H}$ accumulations contained 40 transients, ${ }^{13} \mathrm{C}$ accumulations ca. 1200 transients, ${ }^{14} \mathrm{~N}$ accumulations $c a .200000$ transients, and ${ }^{125} \mathrm{Te}$ accumulations $c a$. 50000 transients. $\mathrm{D}_{2} \mathrm{O}$ was used as an external ${ }^{2} \mathrm{H}$ lock, and TMS, $\mathrm{CH}_{3} \mathrm{NO}_{2}$ and the saturated solution of $\mathrm{H}_{6} \mathrm{TeO}_{6}$ were used as external references. The ${ }^{1} \mathrm{H}$ and ${ }^{13} \mathrm{C}$ chemical shifts are reported relative to TMS, ${ }^{14} \mathrm{~N}$ chemical shifts relative to $\mathrm{CH}_{3} \mathrm{NO}_{2}$ and the ${ }^{125} \mathrm{Te}$ chemical shifts relative to $\mathrm{Me}_{2} \mathrm{Te}\left[\delta\left(\mathrm{Me}_{2} \mathrm{Te}\right)=\right.$ $\left.\delta\left(\mathrm{H}_{6} \mathrm{TeO}_{6}\right)+712\right]$.

MS-EI mass spectra were recorded using a Kratos MS 80 spectrometer at $12 \mathrm{eV}$ of electron energy. The IR spectra were recorded in $\mathrm{KBr}$ disks using a Bruker IFS66 spectrometer. This instrument equipped with a FRA16 Raman unit and a Nd:YAG laser was used to record the Raman spectra directly from the solid samples.

Crystal structure determination. An almost colorless crystal $(0.45 \times 0.30 \times 0.10 \mathrm{~mm})$ was selected for the crystal structure determination. Diffraction data were collected on an Enraf--Nonius CAD4 diffractometer at $173 \mathrm{~K}$ using graphite monochromated Mo $\mathrm{K} \alpha$ radiation $(\lambda=$ $0.71073 \AA$ ). Crystal data and the details of the data collection and structure determination are shown in Table 1 . The unit cell parameters were determined by the
Table 1. Crystal data and details for structure refinement for $\left[\left(\mathrm{CH}_{3} \mathrm{Si}_{2} \mathrm{~N}_{2} \mathrm{TeCl}_{2}\right.\right.$.

\begin{tabular}{|c|c|}
\hline Formula & {$\left[\left(\mathrm{CH}_{3} \mathrm{Si}_{2}\right)_{2} \mathrm{~N}_{2} \mathrm{TeCl}_{2}\right.$} \\
\hline Formula weight & 519.29 \\
\hline Temperature & $173 \mathrm{~K}$ \\
\hline Wavelength & $0.71073 \AA$ \\
\hline Crystal system & Monoclinic \\
\hline Space group & $P 2_{1} / c$ \\
\hline Unit cell dimensions & $\begin{array}{l}a=8.517(2) \AA \\
b=11.667(2) \AA, \beta=91.05(3) \\
c=24.376(5) \AA\end{array}$ \\
\hline Volume & $2421.8(9) \AA^{3}$ \\
\hline$z$ & 4 \\
\hline Density (calculated) & $1.424 \mathrm{Mg} \mathrm{m}^{-3}$ \\
\hline Absorption coefficient & $1.644 \mathrm{~mm}^{-1}$ \\
\hline$F(000)$ & 1056 \\
\hline Crystal size & $0.45 \times 0.30 \times 0.10 \mathrm{~mm}$ \\
\hline$\Theta$-range for data collection & $2.39-24.98^{\circ}$ \\
\hline Index ranges & $\begin{array}{c}0 \leqslant h \leqslant 10,0 \leqslant k \leqslant 13 \\
-28 \leqslant 1 \leqslant 28\end{array}$ \\
\hline Reflections collected & 4257 \\
\hline Independent reflections & 4257 \\
\hline $\begin{array}{l}\text { Observed reflections } \\
{[/>2 \sigma(I)]}\end{array}$ & 2150 \\
\hline Refinement method & $\begin{array}{l}\text { Full-matrix least-squares } \\
\text { on } F^{2}\end{array}$ \\
\hline Data restraints parameters & 42570202 \\
\hline Goodness-of-fit on $F^{2}$ & 0.968 \\
\hline$R$-indices $[I>2 \sigma(I)]^{a}$ & $R_{1}=0.0493, w R_{2}=0.0917$ \\
\hline$R$-indices (all data) ${ }^{a}$ & $R_{1}=0.1761, w R_{2}=0.1156$ \\
\hline $\begin{array}{l}\text { Largest difference peak } \\
\text { and hole }\end{array}$ & 0.835 and $-1.336 \mathrm{e}^{-3}$ \\
\hline
\end{tabular}

least-squares refinement of 25 automatically centered reflections. Two reference reflections were used to monitor the stability of the crystal. Their intensities were recorded periodically after each batch of 98 data. The decay of the crystal appeared to be negligible during the data collection. A total number of 4257 reflections were collected in the $2 \Theta$ range $2-50^{\circ}$. The reflection data were corrected for Lorentz and polarization effects. No absorption correction was applied for the net intensities.

The structure was solved by direct methods using SHELXS-9 $97^{26}$ and refined using SHELXL-97. ${ }^{27}$ After the full-matrix least-squares refinement of the non-hydrogen atoms with anisotropic thermal parameters the hydrogen atoms were placed in calculated positions for the methyl groups $\left(\mathrm{C}-\mathrm{H}=0.96 \AA, \mathrm{H}-\mathrm{C}-\mathrm{H}=109.5^{\circ}\right)$. In the final refinement the hydrogen atoms were riding with the carbon atom to which they were bonded. The isotropic thermal parameters of the hydrogen atoms were fixed at 1.5 times to that of the corresponding carbon atom. The scattering factors for the neutral atoms were those incorporated with the programs. Fractional coordinates and isotropic thermal parameters are listed in Table 2. Selected bond distances and angles are shown in Table 3. The anisotropic thermal parameters, calculated hydrogen atom positions, and all bond parameters are available from the authors upon request. 
Table 2. Atomic coordinates $\left(\times 10^{4}\right)$ and equivalent isotropic displacement parameters $\left(\AA^{2} \times 10^{3}\right)$ for $\left[\left(\mathrm{CH}_{3} \mathrm{Si}_{2}\right)_{2} \mathrm{~N}_{2} \mathrm{TeCl}_{2}{ }^{a}\right.$

\begin{tabular}{lrrrr}
\hline Atom & \multicolumn{1}{l}{$x$} & \multicolumn{1}{l}{$y$} & $U_{\text {eq }}$ \\
\hline $\mathrm{Te}(1)$ & $2505(1)$ & $4603(1)$ & $659(1)$ & $20(1)$ \\
$\mathrm{Cl}(1)$ & $-406(3)$ & $4225(2)$ & $623(1)$ & $30(1)$ \\
$\mathrm{Cl}(2)$ & $5418(3)$ & $4966(2)$ & $724(1)$ & $31(1)$ \\
$\mathrm{Si}(1)$ & $4323(3)$ & $2653(2)$ & $1458(1)$ & $31(1)$ \\
$\mathrm{Si}(2)$ & $2123(3)$ & $1940(2)$ & $495(1)$ & $29(1)$ \\
$\mathrm{Si}(3)$ & $2865(3)$ & $7040(2)$ & $1200(1)$ & $28(1)$ \\
$\mathrm{Si}(4)$ & $815(3)$ & $5332(3)$ & $1839(1)$ & $32(1)$ \\
$\mathrm{N}(1)$ & $2892(8)$ & $3036(6)$ & $934(3)$ & $22(2)$ \\
$\mathrm{N}(2)$ & $2160(8)$ & $5626(6)$ & $1303(3)$ & $23(2)$ \\
$\mathrm{C}(11)$ & $6266(10)$ & $2232(9)$ & $1160(4)$ & $44(3)$ \\
$\mathrm{C}(12)$ & $3493(12)$ & $1390(8)$ & $1838(4)$ & $42(3)$ \\
$\mathrm{C}(13)$ & $4722(12)$ & $3801(8)$ & $1970(4)$ & $38(3)$ \\
$\mathrm{C}(21)$ & $3576(12)$ & $752(8)$ & $407(5)$ & $49(3)$ \\
$\mathrm{C}(22)$ & $293(12)$ & $1291(8)$ & $760(4)$ & $45(3)$ \\
$\mathrm{C}(23)$ & $1823(11)$ & $2502(8)$ & $-214(4)$ & $39(3)$ \\
$\mathrm{C}(31)$ & $3089(12)$ & $7337(8)$ & $459(4)$ & $34(3)$ \\
$\mathrm{C}(32)$ & $1402(12)$ & $8125(8)$ & $1436(4)$ & $44(3)$ \\
$\mathrm{C}(33)$ & $4747(12)$ & $7300(9)$ & $1581(4)$ & $46(3)$ \\
$\mathrm{C}(41)$ & $470(12)$ & $3765(9)$ & $1983(4)$ & $43(3)$ \\
$\mathrm{C}(42)$ & $-1151(11)$ & $6017(9)$ & $1719(4)$ & $43(3)$ \\
$\mathrm{C}(43)$ & $1734(12)$ & $5948(9)$ & $2485(4)$ & $43(3)$ \\
\hline
\end{tabular}

${ }^{a} U_{\mathrm{eq}}$ is defined as one third of the trace of the orthogonalized $U_{i j}$ tensor.

Table 3. Selected bond lengths (in $\AA$ ), bond angles (in ${ }^{\circ}$ ) and torsion angles (in ${ }^{\circ}$ ) in $\left[\left(\mathrm{Me}_{3} \mathrm{Si}_{2}\right)_{2} \mathrm{~N}_{2} \mathrm{TeCl}_{2}\right.$.

\section{Bond lengths}

\begin{tabular}{lllr}
$\mathrm{Te}(1)-\mathrm{N}(1)$ & $1.973(6)$ & $\mathrm{N}(1)-\mathrm{Si}(1)$ & $1.804(7)$ \\
$\mathrm{Te}(1)-\mathrm{N}(2)$ & $1.999(6)$ & $\mathrm{N}(1)-\mathrm{Si}(2)$ & $1.785(7)$ \\
$\mathrm{Te}(1)-\mathrm{Cl}(1)$ & $2.519(2)$ & $\mathrm{N}(2)-\mathrm{Si}(3)$ & $1.775(7)$ \\
$\mathrm{Te}(1)-\mathrm{Cl}(2)$ & $2.519(2)$ & $\mathrm{N}(2)-\mathrm{Si}(4)$ & $1.786(7)$ \\
& & & \\
Bond angles & & & \\
$\mathrm{Cl}(1)-\mathrm{Te}(1)-\mathrm{Cl}(2)$ & $178.36(8)$ & $\mathrm{Cl}(1)-\mathrm{Te}(1)-\mathrm{N}(1)$ & $90.5(2)$ \\
$\mathrm{N}(1)-\mathrm{Te}(1)-\mathrm{N}(2)$ & $108.2(3)$ & $\mathrm{Cl}(1)-\mathrm{Te}(1)-\mathrm{N}(2)$ & $88.5(2)$ \\
$\mathrm{Te}(1)-\mathrm{N}(1)-\mathrm{Si}(1)$ & $125.2(4)$ & $\mathrm{Cl}(2)-\mathrm{Te}(1)-\mathrm{N}(1)$ & $88.7(2)$ \\
$\mathrm{Te}(1)-\mathrm{N}(1)-\mathrm{Si}(2)$ & $113.7(3)$ & $\mathrm{Cl}(2)-\mathrm{Te}(1)-\mathrm{N}(2)$ & $90.5(2)$ \\
$\mathrm{Te}(1)-\mathrm{N}(2)-\mathrm{Si}(3)$ & $112.8(3)$ & $\mathrm{Si}(1)-\mathrm{N}(1)-\mathrm{Si}(2)$ & $118.8(4)$ \\
$\mathrm{Te}(1)-\mathrm{N}(2)-\mathrm{Si}(4)$ & $124.4(4)$ & $\mathrm{Si}(3)-\mathrm{N}(2)-\mathrm{Si}(4)$ & $120.4(4)$ \\
\hline
\end{tabular}

\section{Results and discussion}

The Preparation of $\left[\left(\mathrm{Me}_{3} \mathrm{Si}\right)_{2} \mathrm{~N}_{2} \mathrm{TeCl}_{2}\right.$. Tetrasulfur tetranitride $\mathrm{S}_{4} \mathrm{~N}_{4}$ and tetraselenium tetranitride $\mathrm{Se}_{4} \mathrm{~N}_{4}$ can conveniently be prepared as follows: ${ }^{14-16,20}$

$$
\begin{gathered}
{\left[\left(\mathrm{Me}_{3} \mathrm{Si}\right)_{2} \mathrm{~N}\right]_{2} \mathrm{~S}+\mathrm{SCl}_{2}+\mathrm{SO}_{2} \mathrm{Cl}_{2}} \\
\rightarrow 1 / 2 \mathrm{~S}_{4} \mathrm{~N}_{4}+\mathrm{SO}_{2}+4 \mathrm{Me}_{3} \mathrm{SiCl} \\
{\left[\left(\mathrm{Me}_{3} \mathrm{Si}\right)_{2} \mathrm{~N}\right]_{2} \mathrm{Se}+\mathrm{SeCl}_{4}} \\
\rightarrow 1 / 2 \mathrm{Se}_{4} \mathrm{~N}_{4}+4 \mathrm{Me}_{3} \mathrm{SiCl}
\end{gathered}
$$

We have recently applied the reactions shown above [eqns. (1) and (2)] in the preparation of $1,5-\mathrm{Se}_{2} \mathrm{~S}_{2} \mathrm{~N}_{4} \cdot{ }^{20,21}$

$$
\begin{gathered}
{\left[\left(\mathrm{Me}_{3} \mathrm{Si}\right)_{2} \mathrm{~N}\right]_{2} \mathrm{Se}+\mathrm{SCl}_{2}+\mathrm{SO}_{2} \mathrm{Cl}_{2}} \\
\quad \rightarrow \frac{1}{2} \mathrm{Se}_{2} \mathrm{~S}_{2} \mathrm{~N}_{4}+\mathrm{SO}_{2}+4 \mathrm{Me}_{3} \mathrm{SiCl} \\
{\left[\left(\mathrm{Me}_{3} \mathrm{Si}\right)_{2} \mathrm{~N}\right]_{2} \mathrm{~S}+\mathrm{SeCl}_{4}} \\
\quad \rightarrow \frac{1}{2} \mathrm{Se}_{2} \mathrm{~S}_{2} \mathrm{~N}_{4}+4 \mathrm{Me}_{3} \mathrm{SiCl}
\end{gathered}
$$

Attempts to prepare 1,5- $\mathrm{Te}_{2} \mathrm{~S}_{2} \mathrm{~N}_{4}$ using analogous routes did not lead to the desired product. The reaction of $\left[\left(\mathrm{Me}_{3} \mathrm{Si}\right)_{2} \mathrm{~N}\right]_{2} \mathrm{~S}$ with $\mathrm{TeCl}_{4}$ produces $\mathrm{Cl}_{2}$ TeNSNTe as the main component, in agreement with the results reported by Haas et al. ${ }^{22} \mathrm{We}$ also observed that $\left[\left(\mathrm{Me}_{3} \mathrm{Si}\right)_{2} \mathrm{~N}\right]_{2} \mathrm{TeCl}_{2}$ was the main product when treating $\left[\left(\mathrm{Me}_{3} \mathrm{Si}\right)_{2} \mathrm{~N}\right]_{2}$ Te with $\mathrm{SCl}_{2}$ and $\mathrm{SO}_{2} \mathrm{Cl}_{2}$. It turned out that the product could be prepared in good yields by treating $\left[\left(\mathrm{Me}_{3} \mathrm{Si}\right)_{2} \mathrm{~N}\right]_{2} \mathrm{Te}$ with $\mathrm{SO}_{2} \mathrm{Cl}_{2}$ alone.

$\left[\left(\mathrm{Me}_{3} \mathrm{Si}\right)_{2} \mathrm{~N}\right]_{2} \mathrm{Te}+\mathrm{SO}_{2} \mathrm{Cl}_{2} \rightarrow\left[\left(\mathrm{Me}_{3} \mathrm{Si}\right)_{2} \mathrm{~N}\right]_{2} \mathrm{TeCl}_{2}+\mathrm{SO}_{2}$

Single resonances were observed in ${ }^{1} \mathrm{H}(\delta=0.07 \mathrm{ppm})$, ${ }^{13} \mathrm{C}\left(\delta=1.01 \mathrm{ppm}{ }^{1} J_{\mathrm{HC}}=118 \mathrm{~Hz}\right),{ }^{14} \mathrm{~N}(\delta=-312 \mathrm{ppm})$, and ${ }^{125} \mathrm{Te}(\delta=1510 \mathrm{ppm}) \mathrm{NMR}$ spectra that all could be assigned to $\left[\left(\mathrm{Me}_{3} \mathrm{Si}\right)_{2} \mathrm{~N}\right]_{2} \mathrm{TeCl}_{2}$. The ${ }^{125} \mathrm{Te}$ chemical shifts of some analogous compounds are as follows: $\left(\mathrm{Ph}_{3} \mathrm{PN}\right)_{2} \mathrm{TeCl}_{2}$ and $\left(\mathrm{Ph}_{3} \mathrm{PN}\right)\left(\mathrm{MeO}-\mathrm{C}_{6} \mathrm{H}_{4}\right) \mathrm{TeCl}_{2}$ show resonances at 1604 and $1358 \mathrm{ppm}$, respectively, ${ }^{28}$ and for $\left(\mathrm{Ph}_{2} \mathrm{SN}\right)_{2} \mathrm{TeCl}_{2}, \quad\left(\mathrm{Ph}_{2} \mathrm{CN}\right)_{2} \mathrm{TeCl}_{2}, \quad$ and $\left(\mathrm{Ph}_{2} \mathrm{CN}\right)\left(\mathrm{MeOC}_{6} \mathrm{H}_{4}\right) \mathrm{TeCl}_{2}$ chemical shifts lie at 1760 , 1327 and 1139 ppm, respectively. ${ }^{29}$ The trend in the ${ }^{125} \mathrm{Te}$ chemical shift as a function of the substituents in the $\mathrm{TeCl}_{2}$ fragment is discussed below.

The IR spectroscopic and the mass spectroscopic data are also consistent with $\left[\left(\mathrm{Me}_{3} \mathrm{Si}\right)_{2} \mathrm{~N}\right]_{2} \mathrm{TeCl}_{2}$. The identification of the fragment ions in the mass spectrum was verified by the agreement with the observed and calculated isotopic distributions.

Molecular and crystal structure. The $\left.\left[\left(\mathrm{Me}_{3} \mathrm{Si}\right)_{2} \mathrm{~N}\right]_{2} \mathrm{TeCl}_{2}\right]$ molecule is shown in Fig. 1. It is seen that tellurium shows an approximate trigonal bipyramidal coordination with two axial tellurium-chlorine bonds and two equat-

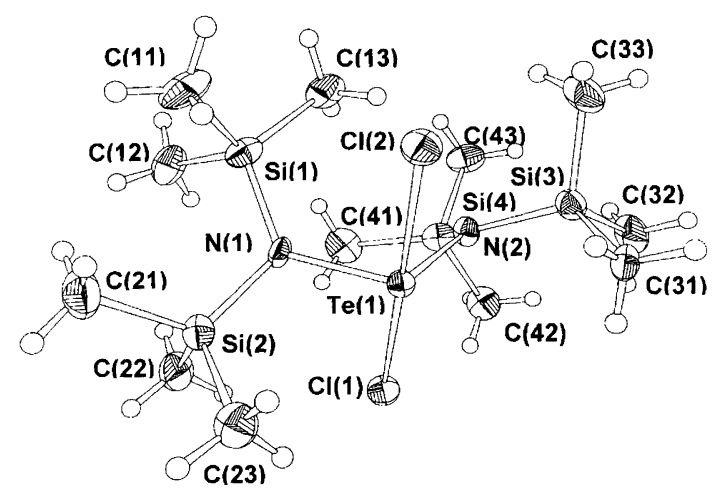

Fig. 1. Molecular structure of $\left[\left(\mathrm{Me}_{3} \mathrm{Si}_{2} \mathrm{~N}_{2} \mathrm{TeCl}_{2}\right.\right.$ indicating the atomic numbering scheme. The thermal ellipsoids have been drawn at $50 \%$ probability level. 
orial tellurium-nitrogen bonds. The third equatorial position is occupied by a lone pair. Some selected bond parameters are presented in Table 3 . The Te(1)-N(1) and $\operatorname{Te}(1)-\mathrm{N}(2)$ bond distances are 1.973(6) and $1.999(6) \AA$, respectively, and both $\mathrm{Te}-\mathrm{Cl}$ distances are $2.519(2) \AA$. The $\mathrm{N}(1)-\mathrm{Te}(1)-\mathrm{N}(2)$ bond angle is $108.2(2)^{\circ}$ and the $\mathrm{Cl}(1)-\mathrm{Te}(1)-\mathrm{Cl}(2)$ bond angle $178.36(8)^{\circ}$ with the chlorine atoms slightly bent towards the equatorial $\left(\mathrm{Me}_{3} \mathrm{Si}\right)_{2} \mathrm{~N}$ groups in accordance with the VSEPR model. The coordination around nitrogen atoms is slightly pyramidal $\left[\Sigma<N=347.1\right.$ and $345.4^{\circ}$ for $\mathrm{N}(1)$ and $\mathrm{N}(2)$, respectively].

The $\mathrm{Te}-\mathrm{N}$ bonds $\left[\left(\mathrm{Me}_{3} \mathrm{Si}\right)_{2} \mathrm{~N}\right]_{2} \mathrm{TeCl}_{2}$ are shorter than single bonds (the sum of the covalent radii of tellurium and nitrogen is $2.07 \AA)^{28}$ implying double bond character, as has previously been deduced for some analogous molecular species containing a four-coordinated tellurium(IV) center. ${ }^{5,23,24,29}$ The $\mathrm{Te}-\mathrm{N}$ bonds arc also significantly shorter than the those in $\left[\left(\mathrm{Me}_{3} \mathrm{Si}\right)_{2} \mathrm{~N}\right]_{2} \mathrm{Te}$ $[2.045(2)$ and 2.053(2) $\AA] .{ }^{25}$

The $\mathrm{Te}-\mathrm{Cl}$ bonds in $\left[\left(\mathrm{Me}_{3} \mathrm{Si}\right)_{2} \mathrm{~N}_{2} \mathrm{TeCl}_{2}\right]$ are relatively long. This is also a characteristic feature in all $\left(\mathrm{R}_{n} \mathrm{MN}\right)_{2} \mathrm{TeCl}_{2}(\mathrm{R}=$ aromatic substituent: $n=2,3: \mathrm{M}=$ C. P. S) species and can easily be explained by the VSEPR model. It is interesting, however, to compare the dependence of the $\mathrm{Te}-\mathrm{Cl}$ bond lengths to those of the $\mathrm{Te}-\mathrm{N}$ bonds ( Table 4). It can be seen that when the Te-N bonds become shorter, the $\mathrm{Te}-\mathrm{Cl}$ bonds get longer. As the $\pi$-effects in the equatorial plane become stronger, the $\mathrm{Cl}-\mathrm{Te}-\mathrm{Cl}$ angle first increases to $180^{\circ}$ and eventually the axial chlorine atoms bend towards the tellurium lone pair. The nature of bonding has been discussed in terms of ionic $\mathrm{E}-\mathrm{Cl}$ bonds that involve the coordination of $\mathrm{Cl}^{-}$anions to the $\pi$-electron stabilized $\left(\mathrm{R}_{n} \mathrm{MN}\right)_{2} \mathrm{E}^{2+}$ cation. ${ }^{5}$ This bonding description is consistent with the observed structural trends in $\left(\mathrm{R}_{n} \mathrm{MN}\right)_{2} \mathrm{TeCl}_{2}$. Further support for the delocalized $\pi$-bonding in the equatorial plane of $\left[\left(\mathrm{Me}_{3} \mathrm{Si}\right)_{2} \mathrm{~N}\right]_{2} \mathrm{TeCl}_{2}$ is obtained by the short $\mathrm{Si}-\mathrm{N}$ bonds of $1.775(7)-1.804(7) \AA$ (the sum of the covalent radii of silicon and nitrogen is $1.87 \AA^{28}$ ).

The ${ }^{125} \mathrm{Te}$ chemical shift also shows a trend that is consistent with the bonding scheme discussed by Björgvinsson and Roesky. ${ }^{5}$ The compounds shown in Table 4 can be divided into two groups: those with two equatorial $\mathrm{Te}-\mathrm{N}$ bonds and those with one equatorial
$\mathrm{Te}-\mathrm{N}$ and one $\mathrm{Te}-\mathrm{C}_{\text {aryl }}$ bond. Within both groups the shielding around tellurium expectedly decreases as the double bond character of the Te-N bond decreases. Direct numerical comparison is not feasible, since the NMR spectra of different molecular species have been recorded in different solvents.

The $\left[\left(\mathrm{Me}_{3} \mathrm{Si}\right)_{2} \mathrm{~N}\right]_{2} \mathrm{TeCl}_{2}$ molecules are packed together through short intermolecular $\mathrm{Te} \cdots \mathrm{Cl}$ contacts $[\mathrm{Te}(1) \cdots \mathrm{Cl}(1)=3.824(2) \AA \quad$ and $\quad \mathrm{Te}(1) \cdots \mathrm{Cl}(2)=$ $3.869(2) \AA$ ] forming a puckered infinite chain. This kind of short intermolecular $\mathrm{Te} \cdots \mathrm{Cl}$ contacts are typical for many $\left(\mathrm{R}_{n} \mathrm{MN}\right)_{2} \mathrm{TeCl}_{2}$ molecules $^{23,24,29}$ and reflect the tendency of tellurium to expand its coordination sphere to five or six. There are some molecules, however, that do not exhibit $\mathrm{Te} \cdots \mathrm{Cl}$ contacts. This is exemplified by $\left(\mathrm{Ph}_{3} \mathrm{PN}\right)_{2} \mathrm{TeCl}_{2}{ }^{28}$ and $\left(\mathrm{Ph}_{2} \mathrm{CN}\right)_{2} \mathrm{TeCl}_{2},{ }^{29}$ for which steric crowding around tellurium prevents intermolecular interaction. Two $\mathrm{Te}-\mathrm{N}$ bonds, two $\mathrm{Te}-\mathrm{Cl}$ bonds and two $\mathrm{Te} \cdots \mathrm{Cl}$ contacts form a six-coordinate packing arrangement in $\left[\left(\mathrm{Me}_{3} \mathrm{Si}\right)_{2} \mathrm{~N}\right]_{2} \mathrm{TeCl}_{2}$, which resembles that in $\mathrm{MeN}[\mathrm{PhBN}(\mathrm{Me})]_{2} \mathrm{TeCl}_{2} \quad$ (Fig. 2). ${ }^{23}$ In $\left(\mathrm{Ph}_{3} \mathrm{PN}\right)\left(\mathrm{C}_{6} \mathrm{H}_{4} \mathrm{OMe}_{4}\right) \mathrm{TeCl}_{2},{ }^{24} \quad\left(\mathrm{Ph}_{2} \mathrm{SN}\right)_{2} \mathrm{TeCl}_{2 .}{ }^{29}$ and $\left(\mathrm{Ph}_{2} \mathrm{CN}\right)\left(\mathrm{C}_{6} \mathrm{H}_{4} \mathrm{OMe}_{4}\right) \mathrm{TeCl}_{2}{ }^{29}$ the four-coordinate tellurium has only one $\mathrm{Te} \cdots \mathrm{Cl}$ contact. In these molecules the coordination polyhedron around tellurium is a distorted square pyramid.

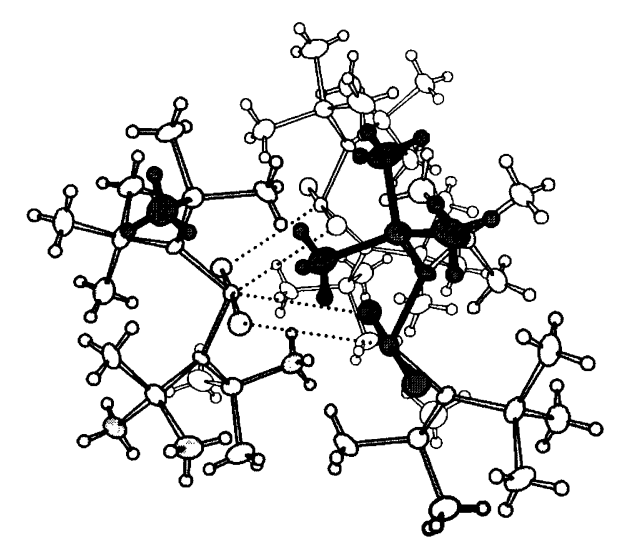

Fig. 2. The packing of $\left[\left(\mathrm{Me}_{3} \mathrm{Si}\right)_{2} \mathrm{~N}_{2} \mathrm{TeCl}_{2}\right.$. The intermolecular $\mathrm{Te}{ }^{\cdots} \mathrm{Cl}$ contacts have been indicated with dotted lines.

Table 4. Average Te-N and Te-Cl bond lengths and intermolecular $\mathrm{Te} \cdots \mathrm{Cl}$ contacts in some $\left(\mathrm{R}_{2} \mathrm{~N}\right)_{x} \mathrm{R}_{2-n}^{\prime} \mathrm{TeCl}_{2}(n=1$ or 2$)$.

\begin{tabular}{llllll}
\hline Molecule & $T / \mathrm{K}$ & $d(\mathrm{Te}-\mathrm{N}) / \AA$ & $d(\mathrm{Te}-\mathrm{Cl}) / \AA$ & $\alpha(\mathrm{Cl}-\mathrm{Te}-\mathrm{Cl}) /^{\circ}$ & $\mathrm{Ref}$. \\
\hline$\left(\mathrm{Ph}_{3} \mathrm{PN}\right)_{2} \mathrm{TeCl}_{2}$ & 293 & 1.918 & 2.603 & $-162.7(1)$ & 24 \\
$\left(\mathrm{Ph}_{3} \mathrm{PN}\right)\left(4-\mathrm{MeOC}_{6} \mathrm{H}_{4}\right) \mathrm{TeCl}_{2}$ & 293 & 1.918 & 2.555 & $-172.7(1)$ & 24 \\
$\left(\mathrm{Ph}_{2} \mathrm{SN}\right)_{2} \mathrm{TeCl}_{2}$ & 153 & 1.954 & 2.582 & $-177.3(1)$ & 29 \\
$\mathrm{MeN}\left[\mathrm{PhBN}\left(\mathrm{Me}_{2}\right]_{2} \mathrm{TeCl}_{2}\right.$ & 293 & 1.964 & 2.523 & $-175.3(1)$ & 23 \\
{$\left[\left(\mathrm{Me}_{3} \mathrm{Si}\right)_{2} \mathrm{Nl}_{2} \mathrm{TeCl}_{2}\right.$} & 173 & 1.986 & 2.519 & $178.36(8)$ & $b$ \\
$\left(\mathrm{Ph}_{2} \mathrm{CN}\right)_{2} \mathrm{TeCl}_{2}$ & 293 & 2.026 & 2.487 & $174.4(1)$ & 29 \\
$\left(\mathrm{Ph}_{2} \mathrm{CN}\right)\left(4-\mathrm{MeOC}_{6} \mathrm{H}_{4}\right) \mathrm{TeCl}_{2}$ & 293 & 2.066 & 2.501 & $176.2(1)$ & 29 \\
\hline
\end{tabular}

${ }^{a}$ Negative value of the angle indicates that the axial chlorine atoms are bent towards the lone pair of the tellurium atom. $A$ positive value implies that the chlorine atoms are bent away from the lone pair. ${ }^{b}$ This work. 
Conclusions. $\left[\left(\mathrm{Me}_{3} \mathrm{Si}\right)_{2} \mathrm{~N}\right]_{2} \mathrm{TeCl}_{2}$ can be prepared in good yields by treating $\left[\left(\mathrm{Me}_{3} \mathrm{Si}\right)_{2} \mathrm{~N}\right]_{2}$ Te with an equimolar amount of $\mathrm{SO}_{2} \mathrm{Cl}_{2}$. The compound is monomeric and exhibits a four-coordinate tellurium with a trigonal bipyramidal geometry with two axial chlorine atoms and two equatorial $\left(\mathrm{Me}_{3} \mathrm{Si}\right)_{2} \mathrm{~N}$ groups. The Te- $\mathrm{N}$ and $\mathrm{Si}-\mathrm{N}$ bonds are shorter than single bonds, and the two $\mathrm{Te}-\mathrm{Cl}$ bonds are rather long. The bonding can be understood in terms of delocalized $\pi$-electron distribution in the equatorial plane and its interaction with the axial chlorine atoms. Close intermolecular $\mathrm{Te} \cdots \mathrm{Cl}$ contacts expand the coordination sphere of tellurium to six.

Acknowledgements. We are indebted to Prof. T. Chivers for helpful discussions. Financial support from the Academy of Finland is gratefully acknowledged.

\section{References}

1. Chivers, T. Chem. Rev. 85 (1985) 341

2. Chivers, T. In The Chemistry of Inorganic Homo- and Heterocycles. Academic Press, London 1987; Vol. 2, pp. 793-869.

3. Oakley, R. T. Prog. Inorg. Chem. 36 (1988) 299.

4. Wentrup, C. and Kambouris, P. Chem. Rev. 91 (1991) 363.

5. Bjögvinsson, M. and Roesky, H. W. Polyhedron 10 (1991) 2353.

6. Klapötke, T. M. In Steudel, R., Ed., The Chemistry of Inorganic Ring Systems. Elsevier, Amsterdam 1992, Vol. 14, pp. 409

7. Haas, A., Kasprowski, J. and Pryka, M. Coord. Chem. Rev. 130 (1994) 301.

8. Chivers, T., Gao, X. and Parvez, M. Inorg. Chem. 35 (1996) 9.

9. Chivers, T., Gao, X. and Parvez, M. Inorg. Chem. 35 (1996) 553.
10. Chivers, T., Gao, X. and Parvez, M. Inorg. Chem. 35 (1996) 4336

11. Wannagat, U. and Kuckertz, H. Angew. Chem. 74 (1962) 117.

12. Lidy, W., Sundermeyer, W. and Verbeek, W. Z. Anorg Allg. Chem. 406 (1974) 228

13. Fockenberg, F. and Haas, A. Z. Naturforsch., Teil B 41 (1986) 413.

14. Chivers, T., Laitinen, R. S., Maaninen, A., Pyykkönen, S. and Siivari, J. Univ. Oulu Rep. Ser. Chem. 42 (1993) P18.

15. Maaninen, A., Siivari, J., Laitinen, R. S. and Chivers, T. Inorg. Synth. In press.

16. Siivari, J., Chivers, T. and Laitinen, R. S. Inorg. Chem. 32 (1993) 1519

17. Garcia-Fernandez, H. Compt. Rend. 258 (1964) 2579.

18. Garcia-Fernandez, H. Bull. Soc. Chim. Fr. (1973) 1210; 1213.

19. Schmitz-DuMont, O. and Ross, B. Angew. Chem. 79 (1967) 1061; Angew. Chem., Int. Ed. Engl. 6 (1967) 1071.

20. Maaninen, A., Siivari, J., Laitinen, R. S. and Chivers, T. Phosphorus Sulfur, Silicon and Relat. Elem. 124/125 (1997) 457.

21. Maaninen, A., Laitinen, R. S., Chivers, T. and Pakkanen, T. A. Inorg. Chem. In press.

22. Haas, A., Kasprowski, J. and Pryka, M. J. Chem. Soc., Chem. Commun. (1992) 1144.

23. Koch, H.-J., Roesky, H. W., Besser, S. and Herbst-Irmer, R. Chem. Ber. 126 (1993) 571.

24. Roesky, H. W., Münzenberg, J., Bohra, R. and Noltemeyer, M. J. Organomet. Chem. 418 (1991) 339.

25. Björgvinsson, M., Roesky,H. W., Pauer, F., Stalke, D. and Sheldrick, G. M. Inorg. Chem. 29 (1990) 5140.

26. Sheldrick. G. M. SHELXS-97. University of Göttingen, Germany 1997.

27. Sheldrick. G. M. SHELXL-97. University of Göttingen, Germany 1997.

28. Emsley, J. The Elements, 2nd Edn. Clarendon Press, Oxford 1991.

29. Münzerberg, J., Roesky, H. W., Noltemeyer, M., Besser, S. and Herbst-Irmer, R. Z. Naturforsch., Teil B 48 (1993) 199.

Received February 9, 1999. 